\title{
New insights into the functional ecology of paramo plants: what growth forms can tell us about plant functional types
}

\author{
Marisol Cruz ${ }^{1}$ and Eloisa Lasso De Paulis ${ }^{2}$ \\ ${ }^{1}$ Universidad de los Andes \\ ${ }^{2}$ Universidad de los Andes Facultad de Ciencias
}

August 23, 2020

\begin{abstract}
Paramos are a unique type of tropical alpine ecosystem. To understand how biodiversity, ecosystem services and community resilience in the paramo will be affected by ongoing environmental change we need to start identifying groups of species with shared characteristics (i.e. functional types or PFTs). This task is particularly challenging as paramos host the highest plant diversity of alpine ecosystems. We measured 22 traits on 42 species belonging to different growth forms in the Colombian Andes. Hierarchical Clustering on Principal Components performed in a Factor analysis of mixed data was used to identify species with similar functional traits and the number of PFTs present. We identified three PFTs; one composed of forbs and shrubs with tender leaves, one composed of only rosettes, and a third group composed by shrubs with tough leaves. If PFTs represent a group of plants that play similar roles in the ecosystem, and have similar responses to perturbation, our results imply that paramos might have limited physiological response and may be highly vulnerable to environmental changes. On the other hand, the presence of multiple species sharing functional traits could provide some resilience, if one species disappears, others may fill the same role and maintain the functionality of the paramo.
\end{abstract}

\section{Original Research Article}

New insights into the functional ecology of paramo plants: what growth forms can tell us about plant functional types

Marisol Cruz ${ }^{1 *}$ and Eloisa Lasso ${ }^{1,2}$

${ }^{1}$ Grupo de Ecología y Fisiología Vegetal, Departamento de Ciencias Biológicas, Universidad de Los Andes, Bogotá, Colombia.

${ }^{2}$ Smithsonian Tropical Research Institute, Panamá, Republica de Panamá.

* Correspondence: m.cruz11@uniandes.edu.co

Abstract: Paramos are a unique type of tropical alpine ecosystem. To understand how biodiversity, ecosystem services and community resilience in the paramo will be affected by ongoing environmental change we need to start identifying groups of species with shared characteristics (i.e. functional types or PFTs). This task is particularly challenging as paramos host the highest plant diversity of alpine ecosystems. We measured 22 traits on 42 species belonging to different growth forms in the Colombian Andes. Hierarchical Clustering on Principal Components performed in a Factor analysis of mixed data was used to identify species with similar functional traits and the number of PFTs present. We identified three PFTs; one composed of forbs and shrubs with tender leaves, one composed of only rosettes, and a third group composed by shrubs with tough leaves. If PFTs represent a group of plants that play similar roles in the ecosystem, and have similar responses to perturbation, our results imply that paramos might have limited physiological response and may be highly vulnerable to environmental changes. On the other hand, the presence of multiple species 
sharing functional traits could provide some resilience, if one species disappears, others may fill the same role and maintain the functionality of the paramo.

Keywords: Andes; functional traits; high elevation grassland; PFT; SLA; tropical alpine ecosystem.

\section{INTRODUCTION}

In the tropical Andes, at elevations above $3,200 \mathrm{~m}$, there is a unique type of tropical alpine ecosystem, locally known as paramo. In the paramo, vegetation has evolved under stressful conditions such as low atmospheric pressure, low temperatures including freezing temperatures, large daily fluctuation in temperatures, intense UV radiation and windy conditions. These conditions, in combination with repeated isolation events throughout geological times and their island-like nature (mountain tops separated by lowlands), have promoted a high rate of speciation (Sklenář and Ramsay, 2001; Madriñán, Cortés and Richardson, 2013; Flantua et al. , 2019), and have resulted in exceptionally high endemism. As result, paramos host an estimated of 3,595 species of vascular plants, $60 \%$ of which are endemic (Luteyn, 1999) including 14 genera that are endemic to the northern Andes (Sklenár and Balslev, 2005). Understanding which of these almost four thousand species could be the most affected by the warming and drying trends expected by the end of this century for the Andes (Urrutia and Vuille, 2009; Buytaert, Cuesta and Tobon, 2011), is an overwhelming challenge. One approach to simplify this challenge is to classify groups of species with shared characteristics or functional traits into plant functional types (PFTs).

The concept of plant functional types proposes that species can be grouped according to common responses to the environment and/or common effects on ecosystem processes. For example, traits like leaf area, foliar nitrogen, and height are related to the species ability to acquire resources and maximize photosynthetic capacity, which is also linked to the capacity to sequester carbon. Traits like water use efficiency and leaf dry matter content (LDCM) and midday leaf water potential are related to the ability to deal with water deficit (Markesteijn et al. , 2011; Martínez-Garza, Bongers and Poorter, 2013), and traits like seed mass, and seed dispersal syndromes are related to reproductive investment, migratory capabilities and establishment success. Some of these traits may affect biogeochemical cycles, invasion resistance, stability in the face of disturbance, net primary productivity (NPP) and therefore can also be linked to species roles in the ecosystem (Dormann, 2002; Lavorel and Garnier, 2002). Functional classification is also thought to be a fundamental tool to reduce the complexity of the floristic composition of plant ecosystems around the globe, to feed global vegetation models (Woodward and Cramer, 1996), to decide what species to use for restoration based on their traits and their roles in the ecosystem (Ostertag et al. , 2015), and for monitoring the effects of global change on vegetation distribution and ecosystem processes (Lavorel and Garnier, 2002). If we can determine the trait profile of species, their putative role in the ecosystem, and how many species share similar roles (the number of PFTs in an ecosystem) we will be closer to understanding how changes in temperature and water availability can modify species composition, and how these changes translate into modifications of ecosystem functioning (i.e. productivity, nutrient cycling, carbon assimilation) through changes in species traits (leaf $\mathrm{C} / \mathrm{N}$ content, photosynthesis) present in the new altered community (Chapin et al. , 2000).

The assignment of species to PFTs is all but straightforward. Some classification schemes use quantitative continuous traits that are assumed to reflect life history trade-offs and involve time-consuming fieldwork. Another approach is to assign species to functional groups based on discrete dominant traits such as growth form, leaf habit, or ability to fix nitrogen, (Ramsay, Kent and Duckworth, 2000; Wrightet al. , 2004; Reich, Wright and Lusk, 2007; Powers and Tiffin, 2010). This second approach represents a fast and relatively easy way to distinguish and characterize functional types. However, the utility and ecological meaning of functional type classifications based on these discrete traits must be evaluated on a case-by-case basis. For example, in the tropical dry forests of Costa Rica, Powers and Tiffin (2010) evaluated if morphological and physiological traits of tropical dry forest tree species varied with leaf habit (i.e. evergreen, deciduous and semi-deciduous species), but found little value in the functional type classification based on leaf habit alone. In contrast, Chapinet al . (1996) demonstrated that plant functional types strongly coincide with growth forms in Artic ecosystems and found strong support for the utility of using growth forms as predictors of the response of Artic environments to global change. For the paramo, there is conflicting evidence about the utility of growth 
forms as a proxy of functional types (Azócar, Rada and García-Núnez, 2000; Cárdenas-Arévalo and VargasRíos, 2008; Rada, Azócar and García-Núñez, 2019), perhaps due to differences in environmental conditions among paramos, the species being studied, and the classification of growth forms used by different authors (see Hedberg and Hedberg, 1979; and Ramsay and Oxley, 1997 for examples of Paramo's classification schemes).

From previous attempt to classify PFTs in the paramo it seems that paramos has few functional groups and that rosettes clearly differ from other growth forms, but whether all shrubs and forbs share common responses and traits is still unclear. Cardenas-Arevalo and Vargas-Ríos (2008) in a Colombian paramo identified only three PFTs after analyzing 70 species and eleven traits, where grasses and bamboos dispersed by anemochory were grouped together, forbs and cushion plants formed a second group and rosettes a third group. Species of shrubs were distributed across different PFTs. From a series of physiological studies on plants from the drier Venezuelan paramos we know that rosettes behave as avoiders, avoiding water deficit and freezing (Azócar, Rada and Goldstein, 1988; Squeo et al. , 1991) whereas grasses, cushion plants and forbs behave as freezing and water deficit tolerators. Shrubs could be either tolerators or avoiders (Rada, Azócar and García-Núñez, 2019). These previous works point to the potential of using growth forms as proxies for PFTs, but more work is needed to understand if the use of growth form is the best approach to classify the vegetation into PFTs in paramos with different climate and vegetation characteristics, to identify what traits are useful for this classification, and to understand whether shrubs can indeed represent many different physiological and ecological strategies. Understanding the functional ecology of paramo plants is crucial given the apparently limited number of physiological strategies identified in those previous studies.

In this study, we evaluated a series of morphological and physiological traits related to water relations and gas exchange, nutrient status, acquisitive strategies and seed dispersal in 42 paramo species belonging to different growth forms. Our main objectives were: 1) to identify the number of plant functional types (PFTs) present in our sample; 2) to determine which traits are crucial for PFT identification; and 3) to establish if PFTs correspond with species growth forms, that is to evaluate how useful growth forms are in defining PFTs in the paramos. The identification of functional types in the paramo could eventually be used to make predictions on the effect of climatic and anthropogenic changes in the diversity and ecosystem processes in this unique tropical ecosystem that covers approximately $36,000 \mathrm{~km}^{2}$, supplies water to the major cities in South America, and stores large quantities of organic carbon in its soils (Hofstede, 1999).

\section{MATERIALS AND METHODS}

\section{Study site and species}

All measurements were taken between October 2013 and March 2015 in the paramo "El VerjónMatarredonda", located in the Eastern Andean range of Colombia ( $\left.4^{\circ} 33^{\prime} \mathrm{N}, 74^{\circ} 00^{\prime} \mathrm{W}\right)$, between 3290 and 3400 m.a.s.l. At this site, the mean annual air temperature is $8^{\circ} \mathrm{C}$, but daily temperature variation is large, with a maximum of $29.6^{\circ} \mathrm{C}$ and a minimum of $2.6^{\circ} \mathrm{C}$, sometimes in a single day (Leon-Garcia and Lasso, 2019). The annual precipitation ranges between 1000 and $1500 \mathrm{~mm} \mathrm{yr}^{-1}$, with a dry season that goes from December through February.

We measured 22 functional traits in 42 species of the most representative and abundant species in the paramo (Table 1 ). Plants were grouped into growth forms following the classification by Ramsay and Oxley (Ramsay and Oxley, 1997): stem rosette, basal rosette, tussock, acaulescent rosette, cushion, upright shrub, prostrate shrub, erect herb, prostrate herb and trailing herb. We have species belonging to seven of these groups; 1) stem rosette with a tall woody stem covered by dead dry leaves with a large apical rosette of live leaves, 2) basal rosette with a large basal rosette of leaves from which a flowering stem eventually arises, 3) acaulescent rosette a small basal rosette of leaves without above ground stems, 4) upright shrubs that includes both tall $(>2 \mathrm{~m})$ and dwarf shrubs with distinctly woody branches with thin bark often with sclerophyllous leaves, 5) prostrate shrubs including all woody creeping dwarf shrubs, 6) erect herbs with erect herbaceous stems often with clustered flowers and 7) prostrate herbs that lack erect stems and possess stolons or other means of spreading vegetatively. We collected samples of the most representative species in 
our site, which is a mix of grassland/shrubland, where shrubs were the most dominant form in this paramo and therefore their high representation in the data set. We collected all the available species with rosette growth forms at the site.

\section{Functional traits}

We measured 22 functional traits, 19 continuous traits and three categorical traits (Table 2 ). Functional traits were measured in three healthy reproductive individuals per species. For functional traits associated to leaves we measured three mature leaves exposed to full light, using the standard protocols from the handbook for easy measurement of plant functional traits worldwide (Cornelissen et al. , 2003). Plant height (m) was measured in the field as the distance from the ground to the top of the main photosynthetic tissues. Leaf area was measured with a flatbed scanner (Hewlett Packard G3010). All weight measurements to estimate specific leaf area (SLA: total leaf area/leaf dry mass $\mathrm{mm}^{2} \mathrm{mg}^{-1}$ ), leaf dry matter content (LDMC): leaf dry mass/leaf fresh mass $\mathrm{mg} \mathrm{g}^{-1}$ ), and seed mass $(\mathrm{mg})$ were obtained using a $0.01 \mathrm{mg}$ precision balance (Sartorius MSE 125p). Leaf dry mass was obtained after drying samples in the oven (Lab-line Imperial $\mathrm{V}$ convection oven $\mathrm{n})$ at $70 @ \mathrm{C}$ for $72 \mathrm{~h})$. Leaf toughness $\left(\mathrm{F}_{\mathrm{p}} \mathrm{N} \mathrm{mm}^{-1}\right)$ was assessed with a punch test using a modified Pesola (Schindellegi Switzerland; (Kitajima and Poorter, 2010)). Leaf thickness (mm) was measured using a $0-25 \mathrm{~mm}$ external micrometer (Redline mechanics). For traits related to nutrient acquisition and nutritional status, leaf nitrogen concentration (LNC, $\mathrm{mg} \mathrm{g}^{-1}$ ), leaf carbon concentration (LCC, $\mathrm{mg} \mathrm{g}^{-1}$ ) and leaf phosphorus concentration ( $\mathrm{LPC}, \mathrm{mg} \mathrm{g}^{-1}$ ), we measured one leaf per individual. The first two were determined by an elemental analyzer and the last one by colorimetric analysis in the Soil and Water laboratory at the Universidad Nacional de Colombia, Bogota.

We also classified species qualitative traits of pubescence, spinescence and dispersal syndrome. Pubescence is a very important characteristic for plants in this ecosystem because it regulates leaf temperature, increases reflectance and may act as first line of defense against herbivores (Hanley et al. , 2007; Seelmann et al. , 2007; Wang et al. , 2015) and may facilitate fog capture and slow release of water, a key trait in the functionality of the paramo as a water reservoir. We defined three categories for this trait: a non-pubescent leaf for glabrous foliar laminas, a high pubescent leaf if it had $>30 \%$ of the lamina covered with trichomes, and low pubescent leaf when $<30 \%$ of the lamina was covered with trichomes. For spinescence, we defined two categories: with and without spines. Data on the dispersal syndrome for each species was obtained from the literature or from personal observations following Pérez-Harguindeguy et al. , 2013, including anemochory (wind dispersal), endozoochory (internal animal transport), exozoochory (external animal transport), hydrochory (dispersal by water) and barochory (dispersion by gravity).

We measured the following traits related to leaf gas exchange and water balance using an open infrared gas exchange analyzer Li-Cor 6400XT (Li-Cor, Lincoln Nebraska): light-saturated photosynthetic rate ( $\mu$ mol $\left.\mathrm{CO}_{2} \mathrm{~m}^{-2} \mathrm{~s}^{-1}\right)$, leaf transpiration rate $\left(\mathrm{mol} \mathrm{H}_{2} \mathrm{O} \mathrm{m}^{-2} \mathrm{~s}^{-1}\right)$, the ratio between intercellular $\mathrm{CO}_{2} /$ ambient $\mathrm{CO}_{2}$, and water use efficiency (how much water is lost for each $\mathrm{CO}_{2}$ assimilated). These values were obtained on sunny mornings during the wet season, between 10:00 and 12:00 hours, setting the light intensity to 1800 $\mu \mathrm{mol}$ photons $\mathrm{m}^{-2} \mathrm{~s}^{-1}$, the $\mathrm{CO}_{2}$ concentration to $400 \mu \mathrm{mol} \mathrm{mol}^{-1}$ and the relative humidity to $60 \%$.

To evaluate the drought tolerance of the species we measured the leaf water potentials at pre-dawn and midday during the end of the dry season. Those values were measured following standard protocols, using a pressure chamber (PMS, Corvallis Oregon). The pre-dawn water potential, when transpiration is at its minimum, provides an indication of the water potential of the soil. Midday water potential is affected by any cuticular and stomatal transpiration and therefore broadly captures the integrated effects of plant traits and the environment on the minimum water potential a plant reaches in natural conditions (Bhaskar and Ackerly, 2006), a value known to be correlated to turgor loss point and other drought tolerance traits (Bartlett et al. , 2016). Additionally, we measured the cuticular conductance $(g \min )$ by registering the change in mass of hydrated leaves as they dried in the laboratory bench for 6-8 hours and measuring the slope after the stomata had closed, following the protocol described in Scoffoni et al. , 2018. Ambient temperature and relative humidity were measured simultaneously and fluctuated minimally during the measurements. Weight measurements were taken using a $0.01 \mathrm{mg}$ precision balance (Sartorius MSE 125p). Leaf area at the 
beginning and at the end of the process was measured with a flatbed scanner (Hewlett Packard G3010).

Each set of traits were always measured during the same week (i.e. one week the height of all plants, one week the leaf area, etc.) or maximum in two weeks for variables that are more time consuming to get, to reduce the variation due to environmental seasonal changes on the traits. Most traits were collected during the rainy season, but on sunny clear days, except for those traits that inform us about species tolerance to drought that were taken at the end of the dry season. Seed mass data was taken whenever the species were reproducing. A detailed list of all measured traits and their probable role is listed inTable 2 .

\section{Data analysis}

After evaluating the correlation matrix of all variables (Figure A1 in the appendix ) we omitted from future analysis two variables that were highly correlated $(>0.8)$; the ratio between intercellular $\mathrm{CO}_{2} /$ ambient $\mathrm{CO}_{2}$ that was highly correlated with WUE and the delta of pre-dawn and midday water potential that was highly correlated with midday water potential.

To show how paramo species are arranged, relative to one another, in the trait space, to evaluate which trait explains most of the observed variation in the data, and to select those traits that could be useful in identifying different PFTs, we used the algorithm of the HCPC (Hierarchical Clustering on Principal Components) method on the 10 first dimensions retained from a Factor analysis of mixed data (FAMD) (metric, Euclidean; linkage, Ward), implemented in the FactoMineR package (Version 1.41) (Kassambara, 2017). We run the FAMD to reduce the dimension of the data into 10 orthogonal axes containing $81 \%$ of the variability of the data. We applied FAMD because it is a principal component method relevant to examine a data set containing both quantitative and qualitative variables (Pagès, 2014). Quantitative and qualitative variables are scaled during the analysis to balance the influence of both types of variables. After that, we ran the hierarchical clustering using the Ward's criterion and letting the analysis pick the optimal number of clusters between 3 to 10 clusters. Finally, we plotted all figures using the Factoextra package (Version 1.0.7) and ggplot2 package (Version 3.1.0).

We explored how the different growth forms contrasted in the multiple trait space using the growth form classification by Ramsay and Oxley (1997) (Figure 1 ) and then used a simpler classification scheme, where prostrate and upright shrubs were classified as shrubs, erect and prostrate herbs as forbs and basal rosettes, stem rosettes and acaulescent rosettes all as rosettes (Figure 2 ).

To examine the variation in all traits among the identified PFTs, we ran ANOVAs and we used Tukey's mean separations tests for variables with normal distribution and ran a Kruskal-Wallis tests and Wilcox tests for variables with a non-normal distribution. All analyses were done using R Studio (Version 1.0.143 R Development Core Team, 2009-2016).

\section{RESULTS}

In the factor analysis of mixed data (FAMD), we found that $42.7 \%$ of the variability could be explained by the three first principal dimensions (Table 3 ). In the first axis of variation, we found traits correlated to the allocation of carbon and light capture (leaf area, SLA, C:N ratio), traits related to defense, such as leaf thickness and toughness, and traits related to plant nutritional status (leaf $\mathrm{N}$ and $\mathrm{P}$ content). On the right side of this axis are grouped together all the stem and basal rosette species and few shrubs species due to their similarity in having thicker and tougher leaves with low SLA and low N and P content, traits which are generally associated with slower growth rates and longer foliar life span (Figure 1). On the left side of this axis are clustered all the forbs (erect and prostrate herbs), one acaulescent rosette and some upright shrubs. These species share having thin and soft leaves with high SLA that are rich in nitrogen and phosphorus, traits associated with high growth rate and an acquisitive strategy (Figure $\mathbf{1}$ and $\mathbf{2}$ ).

On the second axis of variation or dimension 2 we found traits correlated with plant defense and water deficit strategies (LDMC, WUE, water potential at noon, transpiration rate), seed dispersal syndrome, the investment in support and in photosynthetic tissue (LDMC, LCC, SLA and A max ) (Table 3 ). Clustered at the lower end of Dim. 2 are all upright and prostrate shrub species with small, tough expensive leaves and 
with high carbon content whose seeds are dispersed by endo-zoochory with high water use efficiency, low leaf water potential at noon but low photosynthetic rate. Clustered at the higher end of Dim. 2 are all the erect and prostrate herbs and all rosette species. They all have in common high SLA, lower LDMC, seeds dispersed by wind, water or gravity, low WUE, that is, they use more water by each unit of $\mathrm{CO}_{2}$ assimilated, high transpiration rate and photosynthetic rate, and they reach lower leaf water potential at noon (Figure 1 ).

Based on our HCPC analysis, we identified three PFTs (Figure 1 and $\mathbf{2}$ ) that broadly correspond with a coarser classification scheme of the growth forms in the paramo; shrubs, forbs and rosettes. All shrubs, either prostrate and upright shrubs, cluster together; all large rosettes, whether stem or basal rosettes, cluster together, and all erect, and prostrate herbs cluster together (Figure 1 and 2 ). Considering these results, it is reasonable to suggest that we could use a simplified classification of growth forms in the future to feed paramo vegetation models.

The first and larger functional group PFT-1 (circle symbols inFigure 2 ) comprised all forbs and shrubs with relatively tender leaves, belonging mainly to Asteraceae and Melastomataceae families (Table 1 ). This group has thinner leaves, with high SLA, and high nutrient content (nitrogen and phosphorus), probably indicating a leaf rich in lipids, DNA and photosynthetically active enzymes, which would account their slightly higher photosynthetic rate. This set of species is also somewhat tolerant of water deficit with intermediate values of leaf water potential at noon (Figure 3 ).

The second functional group PFT-2 (triangles symbols in Figure 2 ) contains all the rosettes except for one acaulescent rosette species Acaena cylindristachya (Table $\mathbf{1}$ ). Plants in this group have the largest, thickest and toughest leaves of all groups (Figure 3 ), with low SLA generally associated with slow growth rates. Their leaves have high C:N ratios and are low in $\mathrm{N}$ and $\mathrm{P}$ content, making them probably slow to decompose. Their leaves are also densely pubescent, a strategy to reduce water loss and regulate temperature transfer (avoid freezing). Species in this group have low WUE and the highest leaf water potential (less negative) suggesting they are avoiders of water deficit.

The third functional group PFT-3 (square symbols in Figure 2 ) is formed by only shrubs, both prostrate and upright shrubs, including all the species from the Ericaceae family, one Melastomataceae, one Asteraceae among others (Table 1 ). In this PFT-3, we found the tallest shrubs with tough leaves, rich in carbon, but poor in phosphorus, and with a high leaf dry matter content. These shrubs have fruits with heavier seeds dispersed by endo-zoochory, low transpiration rate and low rates of photosynthesis and the most negative values of leaf water potential at noon, an indication that they could be more tolerant of water deficit than the other groups (Figure 3 ).

\section{DISCUSSION}

In this study, after evaluating 42 species and 20 functional traits in one paramo site on the eastern range of the Northern Andes in Colombia, we found that many of the species studied shared similar attributes or functional traits, and they were clustered in three groups or plant functional types (PFTs). Traits that were powerful functional descriptors of PFTs in the paramo were traits related to the leaf nutrient status (C, N and P), leaf toughness, thickness and leaf dry matter content (LDMC), seed dispersal syndromes and physiological traits related to water use efficiency and tolerance to water deficit like $\Psi_{\text {noon }}$, WUE and transpiration rate. Cuticular conductance did not differ among species, among growth forms or among PFTs, and given how time consuming this trait is to measure it could be omitted for future functional classification in the paramo.

We did find some evidence that growth forms correspond to PFTs and could be used to define groups with similar ecological and physiological traits, as was found for the Venezuelan paramos (Rada, Azócar and García-Núñez, 2019) and the tundra (Chapin et al. , 1996). However, for shrubs the story is complex; some species shared traits with the forbs while others form their own group. The classification of upright and prostrate shrub appears to be impractical since both forms were clustered together, and according to our data it would make more sense to classify them into tough and tender leaved shrubs. Where shrubs with 
tough leaves present a series of traits that suggest higher tolerance to water deficit.

One limitation of our study is that we did not include grasses or cushion plants in our analysis and these groups could potentially increase the number of PFTs. However, the increase of functional types is likely to be small if grasses belong to just one PFT as in the Venezuelan paramo where all nine species of grasses studied shared similar water and temperature resistant strategies (Rada, Azócar and García-Núñez, 2019). Similarly, in Chingaza, a different Colombian paramo, Cardenas-Arevalo and Vargas-Ríos (2008) identified only three PFTs after analyzing 70 species, including rosettes, shrubs, forbs, grasses and cushion plants. Although all these findings from different paramos might suggest that paramos have reduced functional responses, we should keep in mind that mountains have complex environmental gradients and various microclimates (Scherrer and Körner, 2011; Sklenář et al. , 2016; Körner and Hiltbrunner, 2018) and that many species show significant variation in functional traits across elevation gradients (Baruch and Smith, 1979; Baruch, 1984; Meinzer, Goldstein and Rundel, 1985; Rada et al. , 1998; Wang et al. , 2016), which suggests a wide acclimation capacity for many species which was not explored here. Our study presents a picture of the functional diversity at a single elevation, but is possible that many of these species can acclimate and modify their traits; understanding species plasticity is key to fully evaluate if the few PFTs identified in paramos imply a limited capacity to respond to changes in the environment.

The paramo hosts the highest plant diversity of alpine ecosystems worldwide (Sklenár. Hedberg and Cleef, 2014), which has hindered our ability to understand the ecology and physiology of most of their species and the ecosystem services they provide. Paramos are entirely different from alpine temperate ecosystems so we cannot assume a priori that the same functional responses that we know from alpine areas apply to the paramo and here we provide some insights into the functional ecology of the paramo. To understand the adaptations and traits of paramo plants we have to take into account that in this tropical alpine ecosystem, temperature variation is not seasonal but diurnal; in a single day differences between absolute minimum and absolute maximum temperatures may exceed 20 to 30K (Sklenáŕ et al. , 2016; Leon-Garcia and Lasso, 2019; Rada, Azócar and García-Núñez, 2019), including freezing temperatures. These species need to withstand great daily temperature changes and freezing temperatures. From studies on the plant response to freezing tolerance in the Venezuelan paramo (Llambí and Rada, 2019), we know that the strategy to deal with freezing temperatures varies among growth forms (Rada, Azócar and García-Núñez, 2019). Rosettes avoid freezing with insulating structure and supercooling, whereas forbs, cushion plants and grasses are freeze tolerant (Azocar, Rada and Goldstein, 1988; Squeo et al. , 1991). However, as we show in our study, shrubs are hard to place in a single strategy; some species avoid freezing (Squeo et al. , 1991), while others tolerate freezing (Azócar, 2006). Less is known about species' tolerance to high temperature, which is the new challenge for plants in a warming world, but from a screening on heat tolerance in 21 paramo species we know that all species can tolerate high temperatures; and irreversible damages to the photosynthetic apparatus occurs when the leaves reaches $45^{\circ} \mathrm{C}$, in some species, or in other species this happens at temperatures as high as $53.9^{\circ} \mathrm{C}$, and rosettes seems to be especially tolerant (Leon-Garcia and Lasso, 2019). Again, growth forms appear to be associated with the strategies to deal with high temperatures, as well as with freezing temperature.

Besides temperature, water availability is also considered one of the most important environmental drivers in the paramo (Rada, Azócar and García-Núñez, 2019). The sudden daily changes in temperatures typical of the paramos also influence water availability. If temperatures descend below zero, water freezes and becomes unavailable, and when temperatures increase on clear days, evaporative demand increases (Ramirez, Rada and Llambí, 2014). Therefore, even in relatively wet paramos, water deficit can occasionally occur, especially in the dry season. The strategies of paramo plants to deal with water deficit also seem to be somewhat related to the growth form (Rada, Azócar and García-Núñez, 2019). In the Venezuelan drier paramos, many species of grasses and shrubs can reach quite low water potentials at noon which suggests they are tolerant of water deficit, while rosettes maintain higher (less negative) water potentials during the day, even in the dry season, which indicates they rely on avoidance mechanisms (Rada, Azócar and García-Núñez, 2019). In fact, many of these stem rosettes are known to store water in their stem pith allowing them to sustain higher water potentials thorough the day (Goldstein, Meinzer and Monasterio, 1984; Meinzer, Goldstein and Rundel, 1985). 
In our study site, a relatively wet paramo, we found that all growth forms analyzed seem to behave more like avoiders with relatively high values (less negative) of noon water potential. However, one of the functional groups identified, the PFT-3, consisting of shrubs with tough leaves, had the lowest water potential at noon, slightly higher values of WUE and higher LDMC (Figure 3; Table A1). A higher LDMC is also associated with having leaves with higher modulus of elasticity (Niinemets, 2001) and more rigid lignified cell walls (Niinemets and Kull, 1998), which could allow them to support lower leaf water potentials and maintain leaf turgor even in periods of lower water availability. High LDMC has also been found to be associated with higher cavitation resistance against drought (Markesteijn et al. , 2011) and is a typical trait associated with higher survival in drier conditions (Martínez-Garza, Bongers and Poorter, 2013) suggesting that this group may be more tolerant of water deficit than the other two groups. In a future drier world paramo species in PFT-3 may have a higher probability of surviving than species in the other PFTs, especially those in the groups of rosettes. On the other hand, based on the Dim. 2 that separates species according to their seed dispersal strategy, shrubs in the PFT-3 are mainly dispersed by endo-zoochory and could migrate longer distances perhaps being more successful in following their climate niche as environmental conditions change, while forbs and rosettes in PFT-1 and 2 whose seeds are dispersed mainly by wind, gravity or water might be too slow to migrate upward.

High mountain regions are warming faster than the lowlands and could be more sensitive to climate change than other ecosystems at the same latitudes (Diaz and Bradley, 1997; Liu and Chen, 2000; Rangwala, Sinsky and Miller, 2013; Ning and Bradley, 2014). Therefore, predicting the responses to climate change of mountain ecosystems has become a major priority. For the tropical high Andes, projections suggest a $3.0 \pm 1.5^{\circ} \mathrm{C}$ rise in the next century (Buytaert, Cuesta and Tobon, 2011), and a decreasing precipitation trend in Northern Colombia and Venezuela, but a small increase in precipitation for Ecuador and Southern Colombia in the next hundred years (Urrutia and Vuille, 2009; Buytaert, Cuesta and Tobon, 2011). While most paramo plants can deal with somewhat higher temperatures (Rada et al. , 1992; Körner, 2003; Rada, Briceño and Azocar, 2008; Leon-Garcia and Lasso, 2019), their response to water deficit could differ greatly among groups and future changes in water availability could change the plant community. The combination of lower precipitation, as projected for the Northern Andes, and higher temperatures, which may increase air evaporative demands and reduce soil water content, could greatly affect plant water relations and gas exchange. For the drier Venezuelan paramo, where many grasses and shrubs are more tolerant of water deficit, the shrub-herbaceous plant community is likely to show some degree of resilience (Llambí and Rada, 2019; Rada, Azócar and García-Núñez, 2019). However, the iconic giant rosettes, common in many of the paramos of the Northern Andes, could suffer in a drier world given their low capacity to tolerate water deficit (Azócar, Rada and García-Núñez, 2000). These giant rosettes are nurse plants with strong facilitation effects and are considered key species in the maintenance of paramo plant diversity (Mora, Llambí and Ramírez, 2019). Additionally, their rosette-like arrangement of heavily pubescent leaves, sometimes forming a basket, facilitates water interception from rain and fog which is then slowly released to the soil, helping in one of the key ecosystem services of the paramo, regulation and provision of water. A paramo without the PFT-2 made by rosettes would definitively lose some of its functionality.

In a future drier paramo the species of shrubs belonging to PFT-3 are the species with a highest chance of withstanding the drier conditions given their higher tolerance to water deficit, and high LDMC values. Yet, even in this group the leaf water potential values were never too negative, indicating that all species, even the more tolerant ones, are probably living on the edge of their safety margin. In previous work in this same paramo, we found that two shrubs species in the genusHypericum were highly vulnerable to xylem cavitation; they lost $50 \%$ of water conductivity at values as high as $-1.50 \mathrm{MPa}$, very close to the lowest leaf water potential measured in the dry season (Ayarza, Garzón-López and Lasso, 2018), an indication of a very narrow safety margin. How changes on $\mathrm{CO}_{2}$ atmospheric concentrations, which has been steadily rising (IPCC, 2014) will interact with the expected changes in water availability in the paramo is unclear, but based on what is known for other ecosystems, an increase in $\mathrm{CO}_{2}$ is likely to mitigate drought stress if plants can reduce their stomatal conductance $\left(g_{\mathrm{s}}\right)$, improve their water use efficiency and increase photosynthesis (Bazzaz, 1990; Körner and Diemer, 1994; Long et al. , 2004). More physiological studies on the vulnerability 
of water deficit of paramo plants and the interaction with $\mathrm{CO}_{2}$ are urgently needed given that water deficit is likely to be one of the threatening environmental driver in a changing paramo. Using this PFT classification we can also guide drought experiments to evaluate whether this classification and set of traits are indeed good indicators of species responses to water deficit and vulnerability to future changes.

Paramos are well known for their role regulating and provisioning water to major cities in South America (Carrillo-Rojas et al. , 2016). They are also important carbon reservoirs in tropical mountains (Hofstede, 1999). There is a growing consensus that the impact of species on ecosystem properties is partially mediated by the traits of their component species (Chapin et al. , 2000; Díaz and Cabido, 2001; Kazakou et al. , 2006) and here we can start discussing how these paramo species from different taxonomic groups might share similar roles in ecosystem functionality (Hubbell, 2005). For example, LDMC and C:N ratios appear to be crucial traits of living leaves that influence the quality of the litter produced, and therefore their 'after-life effects' on ecosystem properties (Kazakou et al. , 2006). Species belonging to PFT-1 with tender leaves with high $\mathrm{N}$ and $\mathrm{P}$ content and low LDMC are probably fast-growing species whose dead leaves will decompose rapidly and help in the rapid turnover of carbon and nutrients. Species in PFT-3 with high LDMC and species in PFT-2 with thicker and tougher leaves and higher C:N ratios decompose slowly, decreasing the liberation of carbon and nutrients to the system, two processes that are important for the role of paramos as carbon reservoirs. In terms of their physiological strategies and their putative role in sequestering carbon, species of forbs and shrubs in PFT-1 show an acquisitive strategy, presenting the highest leaf nitrogen and phosphorus content and slightly higher photosynthetic rate (although not statistically significant), while the rosettes in PFT-2 behave more as conservative species (Reichet al., 2003; Diaz et al. , 2004; Wright et al. , 2004). Photosynthesis is the basis for vegetation growth, but several parameters related to carboxylation efficiency (e.g. Vcmax) at this high elevation are still unknown and are necessary to accurately simulate gross primary production (GPP) and the role of the paramo on the carbon cycle under climate change using Earth System Model predictions. Here we only measured the light-saturated photosynthetic rate and the $\mathrm{Ci} / \mathrm{Ca}$ ratio. However, they both consistently showed no difference among growth forms or PFTs, supporting the optimization of photosynthetic traits hypothesis (Wang et al. , 2016) which suggests that the incorporation of the paramo taxa into global vegetation models (Woodward and Cramer, 1996) could be relatively simplified despite the immense species diversity of the paramo.

Although there is a widespread consensus that growth forms are related to functional adaptations, and that plant traits should reveal the response of these plants to biotic and abiotic stresses in the ecosystem (Westoby et al. , 2002; Reich et al. , 2003; Kattge et al. , 2011), our data suggest some caution in classifying species into PFTs based only on growth forms, especially in the case of shrubs. Clearly shrubs are a complex group that varies from paramo to paramo and even within the same paramo, as our data and those from the Venezuelan paramo indicate. Shrubs presented the largest variance for many traits, suggesting a greater capacity to respond to a broader range of conditions. More growth forms should be analyzed; especially grasses, and seedlings and seed responses need to be evaluated because they could differ from their adult counterparts. This data set represents a baseline to start discussing how species from different taxonomic groups can perhaps share similar roles in the paramo functionality and how much they differ in their strategies to acquire resources and withstand environmental stress. In our study site in the mid paramo, dominated by grasses, shrubs, forbs, and giant rosettes, we did find that rosettes and forbs group into their own functional groups, but shrubs belong to different groups. As in previous screening of functional diversity in the paramos (Cardenas-Arevalo and Vargas-Rios, 2008; Rada, Azocar and Garcia-Nunez, 2019), we also found high redundancy and apparent limited physiological response despite the extremely high plant diversity typical of the paramo.

\section{CONCLUSIONS}

Our results add to a series of studies, which suggest that the paramo, despite being very diverse, has few functional types, and high redundancy, where many species share physiological strategies and traits. However, a careful examination of shrub species and other growth forms such as grasses, sedges and cushion plants is indispensable to fully understand the diversity of functional strategies in the paramo. Future studies 
should expose species from the different PFTs to drier and warmer conditions to understand the differences among PFTs in terms of vulnerability to environmental changes. We also need to better relate PFTs and functional traits to properties and services in the paramo ecosystem like water supply and carbon storage.

\section{REFERENCES}

Ayarza, A., Garzon-Lopez, C. and Lasso, E. (2018) Analisis a multiple escala de las dinamicas hidricas de Hypericum en el paramo. Master thesis. Universidad de los Andes.

Azocar, A., Rada, F. and Garcia-Nunez, C. (2000) 'Aspectos ecofisiologicos para la conservacion de ecosistemas tropicales contrastantes', Boletin de la Sociedad Botanica de Mexico , (65), pp. 89-94.

Azocar, A., Rada, F. and Goldstein, G. (1988) 'Freezing tolerance inDraba chionophila, a miniature caulescent rosette species',Oecologia , 75, pp. 156-160. doi: 10.1007/BF00378830.

Azocar, J. (2006) Relacion entre anatomia foliar, forma de vida y mecanismos de resistencia a temperaturas congelantes en diferentes especies en el Paramo de Piedras Blancas. Universidad de los Andes.

Bartlett, M. K. et al. (2016) 'The correlations and sequence of plant stomatal, hydraulic, and wilting responses to drought',Proceedings of the National Academy of Sciences . National Academy of Sciences, 113(46), pp. 13098-13103. doi: 10.1073/pnas.1604088113.

Baruch, Z. (1984) 'Ordination and classification of vegetation along an altitudinal gradient in the Venezuelan paramos', Vegetation , 55(2), pp. 115-126. doi: 10.1007/BF00037333.

Baruch, Z. and Smith, A. P. (1979) 'Morphological and physiological correlates of niche breadth in two species of Espeletia (Compositae) in the Venezuelan Andes', Oecologia , 38(1), pp. 71-82. doi: 10.1007/BF00347825.

Bazzaz, F. A. (1990) 'The Response of Natural Ecosystems to the Rising Global CO2 Levels', Annual Review of Ecology and Systematics . Annual Reviews, 21(1), pp. 167-196. doi: 10.1146/annurev.es.21.110190.001123.

Bhaskar, R. and Ackerly, D. D. (2006) 'Ecological relevance of minimum seasonal water potentials', Physiologia Plantarum , 127(3), pp. 353-359. doi: 10.1111/j.1399-3054.2006.00718.x.

Buytaert, W., Cuesta, F. and Tobon, C. (2011) 'Potential Impacts of Climate Change on the Environmental Services of Humid Tropical Alpine Regions', Global Ecology and Biogeography , 20, pp. 19-33. doi: 10.1111/j.1466-8238.2010.00585.x.

Cardenas-Arevalo, G. and Vargas-Rios, O. (2008) 'Rasgos de historia de vida de especies en una comunidad vegetal alterada en un paramo humedo (Parque Natural Chingaza)', Caldasia . 30, pp. 245-264.

Carrillo-Rojas, G. et al. (2016) 'Dynamic mapping of evapotranspiration using an energy balance-based model over an Andean Paramo catchment of Southern Ecuador', Remote Sensing. Multidisciplinary Digital Publishing Institute, 8(2), p. 160. doi: 10.3390/rs8020160.

Chapin, F. S. et al. (1996) 'Plant functional types as predictors of transient responses of arctic vegetation to global change',Journal of Vegetation Science, 7(3), pp. 347-358. doi: 10.2307/3236278.

Chapin, F. S. et al. (2000) 'Consequences of changing biodiversity', Nature , 405, pp. 234-242. doi: $10.1038 / 35012241$.

Cornelissen, J. H. C. et al. (2003) 'A handbook of protocols for standardised and easy measurement of plant functional traits worldwide',Australian Journal of Botany , 51(4), pp. 335-380. doi: http://dx.doi.org/10.1071/BT02124.

Diaz, H. and Bradley, R. (1997) 'Diaz HF, Bradley RS. Temperature variations during the last century at High elevation sites.', Climatic Change , 36, pp. 253-279. doi: 10.1023/A:1005335731187. 
Diaz, S. et al. (2004) 'The plant traits that drive ecosystems: Evidence from three continents', Journal of Vegetation Science. Blackwell Publishing Ltd, 15(3), pp. 295-304. doi: 10.1111/j.1654-1103.2004.tb02266.x.

Diaz, S. and Cabido, M. (2001) 'Vive la difference: plant functional diversity matters to ecosystem processes', Trends in Ecology 83 Evolution, 16(11), pp. 646-655. doi: 10.1016/S0169-5347(01)02283-2.

Dormann, S. J. W. (2002) 'Climate change in the Arctic: using plant functional types in a meta-analysis of field experiments',Functional Ecology , 16(1), pp. 4-17.

Flantua, S. G. A. et al. (2019) 'The flickering connectivity system of the north Andean paramos', Journal of Biogeography , 46(8), pp. 1808-1825. doi: 10.1101/569681.

Goldstein, G., Meinzer, F. and Monasterio, M. (1984) 'The role of capacitance in the water balance of Andean giant rosette species.', Plant, Cell and Environment. Blackwell Publishing Ltd, 7(3), pp. 179-186. doi: 10.1111/1365-3040.ep11614612.

Hanley, M. E. et al. (2007) 'Plant structural traits and their role in anti-herbivore defence', Perspectives in Plant Ecology, Evolution and Systematics , 8(4), pp. 157-178. doi: 10.1016/j.ppees.2007.01.001.

Hedberg, I. and Hedberg, O. (1979) 'Tropical-alpine life-forms of vascular plants', Oikos , 33(2), pp. 297-297. doi: $10.2307 / 3544006$.

Hofstede, R. (1999) 'El paramo como espacio para la fijacion de carbono atmosferico', in Medina, G., Mena, P., and Josse, C. (eds) El paramo como espacio de mitigacion de carbono atmosferico . 1st edn. Quito, Ecuador: Abya Yala, p. 57.

Hubbell, S. (2005) 'Neutral theory in community ecology and the hypothesis of functional equivalence', Functional Ecology, 19, pp. 166-172. doi: 10.1111/j.0269-8463.2005.00965.x.

IPCC (2014) Climate Change 2014: Impacts, Adaptation, and Vulnerability. Summaries, Frequently Asked Questions, and Cross-Chapter Boxes. A Contribution of Working Group II to the Fifth Assessment Report of the Intergovernmental Panel on Climate Change, p. 190.

Kassambara, A. (2017) Practical Guide to Cluster Analysis in R: Unsupervised Machine Learning . STHDA (Multivariate Analysis).

Kattge, J. et al. (2011) 'TRY - a global database of plant traits', Global Change Biology . John Wiley \& Sons, Ltd (10.1111), 17(9), pp. 2905-2935. doi: 10.1111/j.1365-2486.2011.02451.x.

Kazakou, E. et al. (2006) 'Co-variations in litter decomposition, leaf traits and plant growth in species from a Mediterranean old-field succession', Functional Ecology , 20, pp. 21-30. doi: 10.1111/j.13652435.2006.01080.x.

Kitajima, K. and Poorter, L. (2010) 'Tissue-level leaf toughness, but not lamina thickness, predicts sapling leaf lifespan and shade tolerance of tropical tree species', New Phytologist , 186(3), pp. 708-721. doi: 10.1111/j.1469-8137.2010.03212.x.

Korner, C. (2003) Alpine plant life: Functional plant ecology of high mountain ecosystems, Alpine Plant Life, 2nd Edn . doi: 10.1007/978-3-642-18970-8.

Korner, C. and Diemer, M. (1994) 'Evidence that plants from high altitudes retain their greater photosynthetic efficiency under elevated $\mathrm{CO}_{2}$ ', Functional Ecology , 8(1), pp. 58-68. doi: 10.2307/2390112.

Korner, C. and Hiltbrunner, E. (2018) 'The 90 ways to describe plant temperature', Perspectives in Plant Ecology, Evolution and Systematics . (Special issue on Alpine and arctic plant communities: a worldwide perspective), 30, pp. 16-21. doi: 10.1016/j.ppees.2017.04.004.

Lavorel, S. and Garnier, E. (2002) 'Predicting changes in community composition and ecosystem functioning from plant traits: Revisiting the Holy Grail', Functional Ecology , 16(5), pp. 545-556. doi: 10.1046/j.13652435.2002.00664.x. 
Leon-Garcia, I. V. and Lasso, E. (2019) 'High heat tolerance in plants from the Andean highlands: Implications for paramos in a warmer world',PLoS ONE , 14(11), pp. 1-14. doi: 10.1371/journal.pone.0224218.

Liu, X. and Chen, B. (2000) 'Climatic warming in the Tibetan plateau during recent decades', International Journal of climatology, 20, pp. 1729-1742. doi: 10.1002/1097-0088.

Llambi, L. and Rada, F. (2019) 'Ecological research in the tropical alpine ecosystems of the Venezuelan paramo: past, present and future',Plant Ecology \& Diversity , pp. 1-20. doi: 10.1080/17550874.2019.1680762.

Long, S. P. et al. (2004) 'Rising atmospheric carbon dioxide: plants FACE the future', Annual Review of Plant Biology , 55, pp. 591-628. doi: 10.1146/annurev.arplant.55.031903.141610.

Luteyn, J. (1999) 'Paramos: A checklist of plant diversity, geographical distribution, and botanical literature. Costa Rica and Panama.', Memoirs of the New York Botanical Garden , 84, pp. 138-141.

Madrinan, S., Cortes, A. J. and Richardson, J. E. (2013) 'Paramo is the world's fastest evolving and coolest biodiversity hotspot',Frontiers in Genetics , 4(192). doi: 10.3389/fgene.2013.00192.

Markesteijn, L. et al. (2011) 'Hydraulics and life history of tropical dry forest tree species: coordination of species' drought and shade tolerance', New Phytologist , 191(2), pp. 480-495. doi: 10.1111/j.14698137.2011.03708.x.

Martinez-Garza, C., Bongers, F. and Poorter, L. (2013) 'Are functional traits good predictors of species performance in restoration plantings in tropical abandoned pastures?', Forest Ecology and Management , 303, pp. 35-45. doi: 10.1016/j.foreco.2013.03.046.

Meinzer, F. C., Goldstein, G. H. and Rundel, P. W. (1985) 'Morphological changes along an altitude gradient and their consequences for an Andean giant rosette plant', Oecologia , 65(2), pp. 278-283. doi: 10.1007/BF00379230.

Mora, M. A., Llambi, L. D. and Ramirez, L. (2019) 'Giant stem rosettes have strong facilitation effects on alpine plant communities in the tropical Andes', Plant Ecology 83 Diversity . Taylor \& Francis, 12(6), pp. 593-606. doi: 10.1080/17550874.2018.1507055.

Niinemets, U. (2001) 'Global-scale climatic controls of leaf dry mass per area, density, and thickness in trees and shrubs', Ecology , 82(2), pp. 453-469. doi: 10.1890/0012-9658(2001)082[0453:GSCCOL]2.0.CO;2.

Niinemets, U. and Kull, O. (1998) 'Stoichiometry of foliar carbon constituents varies along light gradients in temperate woody canopies: implications for foliage morphological plasticity', Tree Physiology, 18(7), pp. 467-479. doi: 10.1093/treephys/18.7.467.

Ning, L. and Bradley, R. (2014) 'Winter precipitation variability and corresponding teleconnections over the Northeastern United States',Journal of Geophysical Research: Atmospheres , 119. doi: 10.1002/2014JD021591.

Ostertag, R. et al. (2015) 'Using plant functional traits to restore Hawaiian rainforest', Journal of Applied Ecology , 52(4), pp. 805-809. doi: 10.1111/1365-2664.12413.

Pages, J. (2014) Multiple factor analysis by example using $R$, p. 253.

Perez-Harguindeguy, N. et al. (2013) 'New handbook for standardized measurement of plant functional traits worldwide', Australian Journal of Botany ,61(3), pp. 167-234. doi: 10.1071/BT12225.

Powers, J. S. and Tiffin, P. (2010) 'Plant functional type classifications in tropical dry forests in Costa Rica: Leaf habit versus taxonomic approaches', Functional Ecology , 24(4), pp. 927-936. doi: 10.1111/j.13652435.2010.01701.x.

Rada, F. et al. (1992) 'Net photosynthesis-leaf temperature relations in plant species with height along an altitudinal gradient', Acta Oecologica , 13(5), pp. 535-542. 
Rada, F. et al. (1998) 'Leaf gas exchange in Espeletia schultzii Wedd, a giant caulescent rosette species, along an altitudinal gradient in the Venezuelan Andes', Acta Oecologica , 19(1), pp. 73-79. doi: 10.1016/S1146609X(98)80010-6.

Rada, F., Azocar, A. and Garcia-Nunez, C. (2019) 'Plant functional diversity in tropical Andean paramos', Plant Ecology \& Diversity , pp. 1-15. doi: 10.1080/17550874.2019.1674396.

Rada, F., Briceno, B. and Azocar, A. (2008) 'How do two Lupinus species respond to temperature along an altitudinal gradient in the Venezuelan Andes?', Revista Chilena De Historia Natural , 81(3). doi: 10.4067/S0716-078X2008000300003.

Ramirez, L., Rada, F. and Llambi, L. (2014) 'Linking patterns and processes through ecosystem engineering: effects of shrubs on microhabitat and water status of associated plants in the high tropical Andes', Plant Ecology , 216(2), pp. 213-225. doi: 10.1007/s11258-014-0429-5.

Ramsay, P., Kent, M. and Duckworth, J. (2000) 'Plant functional types: An alternative to taxonomic plant community description in biogeography?', Progress in Physical Geography, 24, pp. 515-542. doi: $10.1177 / 030913330002400403$.

Ramsay, P. M. and Oxley, E. R. B. (1997) 'The growth form composition of plant communities in the Ecuadorian paramos', Plant Ecology , 131(2), pp. 173-192. doi: 10.1023/A:1009796224479.

Rangwala, I., Sinsky, E. and Miller, J. (2013) 'Amplified warming projections for high altitude regions of the Northern Hemisphere mid-latitudes from CMIP5 models', Environmental Research Letters , 8(2), pp. 24-40. doi: 10.1088/1748-9326/8/2/024040.

Reich, P. B. et al. (2003) 'The evolution of plant functional variation: Traits, spectra, and strategies', International Journal of Plant Sciences , 1643(164), pp. 143-164. doi: 10.1086/374368.

Reich, P. B., Wright, I. J. and Lusk, C. H. (2007) 'Predicting leaf physiology from simple plant and climate attributes: A Global GLOPNET Analysis', Ecological Applications . Ecological Society of America, 17(7), pp. $1982-1988$.

Scherrer, D. and Korner, C. (2011) 'Topographically controlled thermal-habitat differentiation buffers alpine plant diversity against climate warming', Journal of Biogeography , 38(2), pp. 406-416. doi: 10.1111/j.13652699.2010.02407.x.

Scoffoni, C. et al. (2018) 'The causes of leaf hydraulic vulnerability and its influence on gas exchange in Arabidopsis thaliana', Plant Physiology , 178(4), p. 1584 LP - 1601. doi: 10.1104/pp.18.00743.

Seelmann, L. et al. (2007) 'Leaf pubescence mediates intraguild predation between predatory mites', Oikos , 116(5), pp. 807-817. doi: 10.1111/j.2007.0030-1299.15895.x.

Sklenar, P. et al. (2016) 'Temperature microclimates of plants in a Tropical Alpine environment: How much does growth form matter?',Arctic, Antarctic, and Alpine Research , 48(1), pp. 61-78. doi: 10.1657/AAAR0014-084.

Sklenáŕ, P. and Balslev, H. (2005) 'Superpáramo plant species diversity and phytogeography in Ecuador', Flora - Morphology, distribution, functional ecology of plants , 200(5), pp. 416-433. doi: 10.1016/j.flora.2004.12.006.

Sklenář, P., Hedberg, I. and Cleef, A. M. (2014) 'Island biogeography of tropical alpine floras', Journal of Biogeography , 41(2), pp. 287-297. doi: 10.1111/jbi.12212.

Sklenár̆, P. and Ramsay, P. (2001) 'Diversity of zonal páramo plant communities in Ecuador', Diversity and Distributions , 7, pp. 113-124. doi: 10.1046/j.1472-4642.2001.00101.x.

Squeo, F. A. et al. (1991) 'Freezing tolerance and avoidance in high tropical Andean plants: Is it equally represented in species with different plant height?', Oecologia . Springer, 86(3), pp. 378-382. 
Urrutia, R. and Vuille, M. (2009) 'Climate change projections for the Tropical Andes using a regional climate change model: Temperature and precipitation simulations for the 21st Century', Journal of Geophysical Research , 114. doi: 10.1029/2008JD011021.

Wang, H. et al. (2016) 'Photosynthetic responses to altitude: an explanation based on optimality principles', New Phytologist , 213(3). doi: 10.1111/nph.14332.

Wang, X. et al. (2015) 'Herbivore defense responses and associated herbivore defense mechanism as revealed by comparing a resistant wild soybean with a susceptible cultivar', Crop Journal , 3(6), pp. 451-467. doi: 10.1016/j.cj.2015.07.001.

Westoby, M. et al. (2002) 'Plant ecological strategies: Some leading dimensions of variation between species', Annual Review of Ecology and Systematics , 33(1), pp. 125-159. doi: 10.1146/annurev.ecolsys.33.010802.150452.

Woodward, F. I. and Cramer, W. (1996) 'Plant functional types and climatic change: Introduction', Journal of Vegetation Science, 7(3), pp. 306-308. doi: 10.1111/j.1654-1103.1996.tb00489.x.

Wright, I. J. et al. (2004) 'The worldwide leaf economics spectrum', Nature, 428, p. 821.

\section{TABLES}

Table 1. List of studied species organized by family, growth forms (GF), and area of occurrence. Occurrences were obtained from GBIF (https://www.gbif.org/en/). We considered as a valid country of occurrence if there were more than one specimen recorded in that country. If a species was listed in more than four South American countries is registered as South America. Accepted species names and authorities are from the Plant List (http://www.theplantlist.org/). The last column shows the PFTs to which the species belong after our cluster analysis. Growth forms are as follow: US = Upright shrub; PS = Prostrate shrubs, SR $=$ Stem rosette; $\mathrm{BR}=$ Basal rosette, $\mathrm{AR}=$ Acaulescent rosette, $\mathrm{PH}=$ Reptant and prostrate herbs, and $\mathrm{EH}=$ Erect herbs.

\begin{tabular}{lll}
\hline Scientific name & Family & GF \\
\hline Shrubs & & \\
Oreopanax mutisianus (Kunth) Decne. \& Planch. & Araliaceae & US \\
Ageratina asclepiadea (L.f.) R.M.King \& H.Rob. & Asteraceae & US \\
Ageratina gynoxoides (Wedd.) R.M.King \& H.Rob. & Asteraceae & US \\
Baccharis bogotensis Kunth & Asteraceae & US \\
Baccharis tricuneata (L.f.) Pers. & Asteraceae & US \\
Pentacalia firmipes (Greenm.) Cuatrec. & Asteraceae & US \\
Pentacalia ledifolia (Kunth) Cuatrec. & Asteraceae & US \\
Pentacalia nitida (Kunth) Cuatrec. & Asteraceae & US \\
Pentacalia vaccinioides (Kunth) Cuatrec. & Asteraceae & US \\
Diplostephium phylicoides (Kunth) Wedd. & Asteraceae & US \\
Diplostephium rosmarinifolium (Benth.) Wedd. & Asteraceae & US \\
Berberis goudotii Triana \& Planch. & Berberidaceae & US \\
Bejaria resinosa Mutis ex L.f. & Ericacea & US \\
Gaultheria anastomosans (Mutis ex L.f.) Kunth & Ericacea & US \\
Gaultheria hapalotricha A.C.Sm. & Ericacea & PS \\
Macleania rupestris (Kunth) A.C.Sm. & Ericaceae & US \\
Gaultheria myrsinoides Kunth (syn Pernettya prostrate) & Ericacea & PS \\
Ribes andicola Jancz. & Grossulariaceae & US \\
Brachyotum strigosum (L. f.) Triana & Melastomataceae & US \\
Bucquetia glutinosa (L. f.) DC. & Melastomataceae & US \\
Miconia summa Cuatrec. & Melastomataceae & US \\
Tibouchina grossa (L. f.) Cogn. & Melastomataceae & US
\end{tabular}




\begin{tabular}{|c|c|c|}
\hline Scientific name & Family & GF \\
\hline Monnina salicifolia Ruiz \& Pav. & Polygalaceae & US \\
\hline Myrsine dependens (Ruiz \& Pav.) Spreng. & Primulaceae & US \\
\hline Hesperomeles obtusifolia (DC.) Lindl.* & Rosaceae & US \\
\hline Rubus acanthophyllos Focke* & Rosaceae & US \\
\hline Symplocos theiformis (L. f.) Oken & Symplocaceae & US \\
\hline \multicolumn{3}{|l|}{ Rosettes } \\
\hline Espeletia grandiflora Humb. \& Bonpl. & Asteraceae & $\mathrm{SR}$ \\
\hline Espeletiopsis corymbosa (Humb. \& Bonpl.) Cuatrec. & Asteraceae & SR \\
\hline Espeletia argentea Humb. \& Bonpl. & Asteraceae & $\mathrm{BR}$ \\
\hline Eryngium humboldtii F.Delaroche & Apiaceae & $\mathrm{BR}$ \\
\hline Greigia stenolepis L.B.Sm. & Bromeliaceae & $\mathrm{BR}$ \\
\hline Puya goudotiana $\mathrm{Mez}$ & Bromeliaceae & $\mathrm{BR}$ \\
\hline Puya santosii Cuatrec. & Bromeliaceae & $\mathrm{BR}$ \\
\hline Paepalanthus alpinus Körn. (Syn Paepalanthus columbiensis) & Eriocaulaceae & $\mathrm{BR}$ \\
\hline Acaena cylindristachya Ruiz \& Pav* & Rosaceae & $\mathrm{AR}$ \\
\hline \multicolumn{3}{|l|}{ Forbs } \\
\hline Geranium multiceps Turcz. & Geraniaceae & $\mathrm{PH}$ \\
\hline Geranium sibbaldioides Benth. & Geraniaceae & $\mathrm{PH}$ \\
\hline Lachemilla orbiculata (Ruiz \& Pav.) Rydb* & Rosaceae & $\mathrm{PH}$ \\
\hline Orthrosanthus chimboracensis (Kunth) Baker & Iridaceae & $\mathrm{EH}$ \\
\hline Senecio formosoides Cuatrec. & Asteraceae & $\mathrm{EH}$ \\
\hline Valeriana pilosa Ruiz \& Pav. & Caprifoliaceae & $\mathrm{EH}$ \\
\hline * Unresolved name in The Plan List. & * Unresolved name in The Plan List. & * Unresolved name \\
\hline
\end{tabular}

Table 2. Functional traits measured in the paramo plants and their probable relation with processes and functions.

\begin{tabular}{|c|c|c|}
\hline Functional trait & Abbrev. & Related with \\
\hline \multicolumn{3}{|l|}{ Continuous traits and units } \\
\hline Plant height $(\mathrm{m})$ & $\mathrm{H}$ & $\begin{array}{l}\text { Competitiveness, robustness, } \\
\text { potential strength, fecundity, } \\
\text { carbon storage, light acquisition }\end{array}$ \\
\hline Seed mass (mg) & $\mathrm{SM}$ & $\begin{array}{l}\text { Dispersal, establishment, } \\
\text { survival, competitiveness }\end{array}$ \\
\hline Leaf area $\left(\mathrm{mm}^{2}\right)$ & LA & $\begin{array}{l}\text { Resource acquisition, allometric } \\
\text { factors and environmental } \\
\text { stresses }\end{array}$ \\
\hline Specific leaf area $\left(\mathrm{mm}^{2} \mathrm{mg}^{-1}\right)$ & SLA & $\begin{array}{l}\text { Relative Growth Rate (RGR) } \\
\text { and environmental conditions }\end{array}$ \\
\hline $\begin{array}{l}\text { Leaf dry matter content }(\mathrm{mg} \\
\left.\mathrm{g}^{-1}\right)\end{array}$ & LDMC & $\begin{array}{l}\text { Leaf density, decomposition } \\
\text { rates and plant defense. }\end{array}$ \\
\hline Leaf thickness (mm) & LT & $\begin{array}{l}\text { Defense, carbon balance, } \\
\text { resource acquisition and use, } \\
\text { longevity }\end{array}$ \\
\hline $\begin{array}{l}\text { Physical strength of leaves (N } \\
\mathrm{mm}^{-1} \text { ) }\end{array}$ & LS & $\begin{array}{l}\text { Defense, mechanical damage, } \\
\text { anatomical variation, longer leaf } \\
\text { lifespans, carbon investment. }\end{array}$ \\
\hline $\begin{array}{l}\text { Leaf water potential at } \\
\text { pre-dawn }(\mathrm{MPa})\end{array}$ & $\Psi_{\text {pre-dawn }}$ & $\begin{array}{l}\text { Water status and hydraulic } \\
\text { strategies }\end{array}$ \\
\hline
\end{tabular}




\begin{tabular}{|c|c|c|}
\hline Functional trait & Abbrev. & Related with \\
\hline $\begin{array}{l}\text { Leaf water potential at noon } \\
(\mathrm{MPa}) \\
\Delta \text { Leaf Water potential between } \\
\text { noon and pre-dawn }\end{array}$ & $\Psi_{\text {noon }}$ & $\begin{array}{l}\text { Water status and hydraulic } \\
\text { strategies } \\
\text { Hydraulic strategies }\end{array}$ \\
\hline $\begin{array}{l}\text { Light-saturated photosynthetic } \\
\text { rate }\left(\mu \mathrm{mol} \mathrm{m} \mathrm{m}^{-2} \mathrm{~s}^{-1}\right)\end{array}$ & $\mathrm{A}_{\max }$ & $\begin{array}{l}\text { Metabolic capacity and leaf } \\
\text { economic spectrum }\end{array}$ \\
\hline $\begin{array}{l}\text { Leaf transpiration rate }\left(\mathrm{mol} \mathrm{m}^{-2}\right. \\
\left.\mathrm{s}^{-1}\right)\end{array}$ & $\mathrm{E}$ & $\begin{array}{l}\text { Photosynthetic rates, physical leaf } \\
\text { characteristics and hydraulic } \\
\text { strategies. }\end{array}$ \\
\hline Intercellular $\mathrm{CO}_{2} / \mathrm{Ambient} \mathrm{CO}_{2}$ & $\mathrm{C}_{\mathrm{i}} / \mathrm{C}_{\mathrm{a}}$ & $\begin{array}{l}\text { Related to stomatal limitations } \\
\text { of gas exchange when it is } \\
\text { compared with stomatal } \\
\text { conductance. }\end{array}$ \\
\hline $\begin{array}{l}\text { Water use efficiency }\left(\mu \mathrm{mol} \mathrm{CO}_{2}\right. \\
\left.\mathrm{mmol} \mathrm{H}^{-1}\right)\end{array}$ & WUE & $\begin{array}{l}\text { Carbon balance, water use } \\
\text { efficiency, resource use and } \\
\text { acquisition }\end{array}$ \\
\hline $\begin{array}{l}\text { Leaf phosphorus content (mg } \\
\mathrm{g}^{-1} \text { ) }\end{array}$ & LPC & $\begin{array}{l}\text { Leaf quality, nutritional quality } \\
\text { of the soil }\end{array}$ \\
\hline Leaf carbon content $\left(\mathrm{mg} \mathrm{g}^{-1}\right)$ & $\mathrm{LCC}$ & Leaf construction, resource use \\
\hline Leaf nitrogen content $\left(\mathrm{mg} \mathrm{g}^{-1}\right)$ & $\mathrm{LNC}$ & $\begin{array}{l}\text { Concentration of RuBisCO, } \\
\text { photosynthesis and fast-to-slow } \\
\text { strategy, nutritional quality of } \\
\text { the soil }\end{array}$ \\
\hline Leaf C:N & $\mathrm{C}: \mathrm{N}$ & Decomposition rate \\
\hline $\begin{array}{l}\text { Cuticular conductance }(\mathrm{mmol} \\
\left.\mathrm{m}^{-2} \mathrm{~s}^{-1}\right) \\
\text { Categorical traits }\end{array}$ & $g_{\min }$ & $\begin{array}{l}\text { Drought tolerance and water } \\
\text { balance }\end{array}$ \\
\hline Spinescence & & $\begin{array}{l}\text { Defense, correlated with } \\
\text { drought and grazing pressure }\end{array}$ \\
\hline Pubescence & & $\begin{array}{l}\text { Regulation of leaf temperature } \\
\text { and water loss }\end{array}$ \\
\hline Dispersal syndrome & & $\begin{array}{l}\text { Competitiveness, robustness, } \\
\text { potential establishment, } \\
\text { migration capability }\end{array}$ \\
\hline
\end{tabular}

Table 3 . Contribution of the analyzed plant traits to the first three dimensions of the factor analysis of mixed data (FAMD). The highest values for each dimension are indicated in bold. At the end the percentage of the total variance explained by each dimension is shown.

\begin{tabular}{llll}
\hline Variables & Dim. 1 & Dim. 2 & Dim. 3 \\
\hline Leaf thickness & $\mathbf{1 3 . 5 1}$ & 0.01 & 1.35 \\
Leaf Nitrogen content (LNC) & $\mathbf{1 3 . 0 9}$ & 0.36 & 0.13 \\
Physical strength of leaves & $\mathbf{1 2 . 0 2}$ & 0.16 & 5.39 \\
Leaf C:N ratio & $\mathbf{1 0 . 9 1}$ & 1.23 & 0.23 \\
Leaf phosphorus content (LPC) & $\mathbf{9 . 7 2}$ & 0.42 & 0.12 \\
Leaf area & $\mathbf{9 . 2 9}$ & 3.42 & 0.13 \\
Specific leaf area (SLA) & $\mathbf{7 . 8 9}$ & $\mathbf{7 . 4 4}$ & 7.93 \\
Spinescence of leaves & $\mathbf{5 . 7 2}$ & 1.38 & 7.19 \\
Leaf dry matter content (LDMC) & 0.23 & $\mathbf{1 7 . 5 4}$ & 1.39
\end{tabular}




\begin{tabular}{llll}
\hline Variables & Dim. 1 & Dim. 2 & Dim. 3 \\
\hline Seed dispersal & 4.55 & $\mathbf{1 6 . 7 5}$ & $\mathbf{1 8 . 1 5}$ \\
Leaf carbon content $(\mathrm{LCC})$ & 0.04 & $\mathbf{9 . 0 1}$ & $\mathbf{1 1 . 6 5}$ \\
Leaf transpiration rate $(\mathrm{E})$ & 2.66 & $\mathbf{8 . 4 5}$ & 3.29 \\
Light-saturated photosynthetic rate $\left(\mathrm{A}_{\max }\right)$ & 0.06 & $\mathbf{6 . 8 4}$ & $\mathbf{1 7 . 4 3}$ \\
Leaf water potential at noon $\left(\Psi_{\text {noon }}\right)$ & 0.43 & $\mathbf{6 . 7 5}$ & 4.48 \\
Water use efficiency $(\mathrm{WUE})$ & 5.10 & $\mathbf{6 . 0 6}$ & 1.23 \\
Plant height & 1.34 & 4.68 & $\mathbf{1 2 . 7 7}$ \\
Pubescence of leaves & 0.97 & 6.01 & 5.63 \\
Seed mass & 0.05 & 0.90 & 1.18 \\
Cuticular conductance $\left(\mathrm{g}_{\text {min }}\right)$ & 2.38 & 1.91 & 0.29 \\
Leaf water potential at pre-dawn $\left(\Psi_{\text {pre-dawn }}\right)$ & 0.04 & 0.68 & 0.00 \\
\% of total variance explained & $\mathbf{1 9 . 4 7}$ & $\mathbf{1 3 . 5 4}$ & $\mathbf{9 . 7 1}$ \\
\hline
\end{tabular}

\section{DATA ACCESSIBILITY STATEMENT}

Data, and scripts used to generate the analysis presented are available via Dryad or figshare at this xxx location. Data will be uploaded upon acceptance of the Manuscript.

\section{COMPETING INTEREST STATEMENT}

The authors declare no conflict of interest. The funders had no role in the design of the study; in the collection, analyses, or interpretation of data; in the writing of the manuscript, or in the decision to publish the results.

All samples come from one single site located in the Eastern Andean range of Colombia ( $4^{\circ} 33^{\prime} \mathrm{N}, 74^{\circ} 00^{\prime}$ W), and were collected between October 2013 and March 2015. For the collection of traits, we collected mostly leaves, sometimes branches and few fruits per individual to measure their seeds, all collection were limited and should not affect the population at the site.

Samples were collected under the collection permit "Master Permit for the Collection of Wild Species Specimens from the Biological Diversity for Non-commercial Scientific Research Purposes" (in its original language "Permiso Marco de Recoleccion de Especimenes de Especies Silvestres de la Diversidad Biologica con fines de Investigacion Cientifica No Comercial") granted by the National Environmental Licensing Authority through resolution No. 1177 of October 9, 2014 to the University of the Andes and to researcher E. Lasso under the research project "Impact of climate change on plant biodiversity in Paramo, and on the ecosystem service it provides us as a carbon sink" (permit number: IBD0359). Voucher specimens are accessible in University of los Andes herbarium (ANDES).

\section{AUTHOR CONTRIBUTIONS}

Conceptualization, M.C. and E.L.; methodology, M.C. and E.L; validation, M.C. and E.L.; formal analysis, M.C.; investigation, M.C.; resources, E.L. data curation, M.C.; writing - original draft preparation, M.C. and E.L.; writing - review and editing, M.C. and E.L.; visualization, M.C. and E.L.; supervision, E.L.; project administration, M.C. and E.L.; funding acquisition, M.C. and E.L. All authors have read and agreed to the published version of the manuscript.

\section{ACKNOWLEDGMENTS}

Special thanks to all the people that helped collecting data in the field and in the lab: Rafael Lara, Sandra Estrada, Felipe Avila, Alejandra Ayarza, Andrea Rojas and to Indira Leon for drawing the different growth forms presented in all figures and for helping in the field. We would like to thank the Sabogal family for allowing the collection of samples in paramo el Verjon and the "Parque Ecológico Matarredonda". Additionally, we would like to thank Adolfo Amézquita for his guidance during data analysis, James Dalling 
for reviewing and editing the last version of this manuscript and Fermín Rada, Barbara Scott M, Gordon Murdock, Rebecca Montgomery who made valuable suggestions that further improved this manuscript.

This research was funded by Colciencias Patrimonio autónomo fondo nacional de financiamiento para la ciencia, la tecnología y la innovación Francisco José de Caldas", grant number 120471451294,also by the following grants from University of los Andes: "Fondo de Investigaciones para apoyar programas de profesores de la Facultad de Ciencias de la Universidad de los Andes, grant number INV-2019-84-1805 and "Fondo semilla" grant INV-2017-26-1118 and INV-2019-86-1807.

\section{APPENDIX}

Table A1. Functional traits variation between the three PFTs identified in the paramo "El Verjón". Statistical differences from the ANOVAS and Kruskal-Wallis test are shown next to the trait using *** for $\mathrm{P}<0.001$, ${ }^{* *}$ for $\mathrm{P}<0.01$, and ${ }^{*}$ for $\mathrm{P}<0.05$. Plant functional traits that do not share a lowercase letter are statistically different from one another as determined by post-hoc Tukey's and Wilcox test.

\begin{tabular}{|c|c|c|c|c|}
\hline Functional Traits & $\begin{array}{l}\text { PFT } 1 \\
\text { (Forbs and tender leaves shrubs) }\end{array}$ & $\begin{array}{l}\text { PFT } 2 \\
\text { (Only rosettes) }\end{array}$ & $\begin{array}{l}\text { PFT } 3 \\
\text { (Hard leaf shrubs) }\end{array}$ & $\begin{array}{l}\text { Statistics } \\
\text { and } \mathrm{p} \text {-val } \\
(\mathrm{df}=2 \text { fo }\end{array}$ \\
\hline Plant height & $1.15 \pm 0.19^{\mathrm{a}}$ & $0.59 \pm 0.07^{\mathrm{a}}$ & $1.19 \pm 0.17^{\mathrm{a}}$ & $\mathrm{Chi}^{2}=$ \\
\hline Seed mass $* *$ & $0.18 \pm 0.05^{\mathrm{a}}$ & $0.39 \pm 0.07^{\mathrm{b}}$ & $18.32 \pm 11.93^{\mathrm{b}}$ & $\mathrm{Chi}^{2}=$ \\
\hline Leaf area** & $1347.7 \pm 441.2^{\mathrm{a}}$ & $9251.4 \pm 1526.6^{\mathrm{b}}$ & $571.6 \pm 218.6^{\mathrm{a}}$ & $\mathrm{Chi}^{2}=$ \\
\hline $\mathrm{SLA} * * *$ & $8.5 \pm 0.6^{\mathrm{a}}$ & $5.3 \pm 0.8^{\mathrm{b}}$ & $4.9 \pm 0.4^{\mathrm{b}}$ & $\mathrm{Chi}^{2}=$ \\
\hline $\mathrm{LDMC}^{* * *}$ & $369.0 \pm 16.9^{\mathrm{a}}$ & $311.7 \pm 14.7^{\mathrm{a}}$ & $474.1 \pm 21.4^{\mathrm{b}}$ & $\mathrm{F}=12$ \\
\hline Leaf thickness $* * *$ & $0.29 \pm 0.02^{\mathrm{a}}$ & $0.70 \pm 0.06^{\mathrm{b}}$ & $0.42 \pm 0.04^{\mathrm{c}}$ & $\mathrm{Chi}^{2}=$ \\
\hline Leaf toughness ${ }^{* * *}$ & $0.88 \pm 0.20^{\mathrm{a}}$ & $4.71 \pm 0.54^{\mathrm{b}}$ & $1.89 \pm 0.34^{\mathrm{c}}$ & $\mathrm{Chi}^{2}=$ \\
\hline Leaf water potential at pre-dawn & $-0.28 \pm 0.03^{\mathrm{a}}$ & $-0.33 \pm 0.01^{\mathrm{a}}$ & $-0.29 \pm 0.03^{\mathrm{a}}$ & $\mathrm{Chi}^{2}=$ \\
\hline Leaf water potential at noon* & $-1.32 \pm 0.09^{\mathrm{ab}}$ & $-1.13 \pm 0.08^{\mathrm{a}}$ & $-1.72 \pm 0.17^{\mathrm{b}}$ & $\mathrm{Chi}^{2}=$ \\
\hline Light-saturated photosynthetic rate & $7.82 \pm 0.53^{\mathrm{a}}$ & $7.48 \pm 1.06^{\mathrm{a}}$ & $5.64 \pm 0.95^{\mathrm{a}}$ & $\mathrm{F}=1$ \\
\hline Intercellular $\mathrm{CO}_{2} /$ Ambient $\mathrm{CO}_{2}$ & $0.34 \pm 0.06 \mathrm{a}$ & $0.48 \pm 0.10 \mathrm{a}$ & $0.31 \pm 0.06 \mathrm{a}$ & $\mathrm{Chi}^{2}=$ \\
\hline Leaf transpiration rate re* $^{* * *}$ & $0.0043 \pm 0.0003^{\mathrm{a}}$ & $0.0027 \pm 0.0002^{\mathrm{b}}$ & $0.0023 \pm 0.0002^{\mathrm{b}}$ & $\mathrm{Chi}^{2}=$ \\
\hline Water use efficiency & $0.69 \pm 0.06^{\mathrm{a}}$ & $0.49 \pm 0.06^{\mathrm{a}}$ & $0.75 \pm 0.05^{\mathrm{a}}$ & $\mathrm{Chi}^{2}=$ \\
\hline Leaf phosphorus content $* * *$ & $1.36 \pm 0.09^{\mathrm{a}}$ & $0.79 \pm 0.05^{\mathrm{b}}$ & $0.91 \pm 0.07^{\mathrm{b}}$ & $\mathrm{Chi}^{2}=$ \\
\hline Leaf carbon content $* *$ & $457.1 \pm 4.7^{\mathrm{a}}$ & $445.4 \pm 2.8^{\mathrm{a}}$ & $479.7 \pm 7.8^{\mathrm{b}}$ & $\mathrm{F}=6$ \\
\hline Leaf nitrogen content ${ }^{* * *}$ & $17.0 \pm 0.69^{\mathrm{a}}$ & $11.3 \pm 0.44^{\mathrm{b}}$ & $13.5 \pm 0.80^{\mathrm{b}}$ & $\mathrm{F}=13$ \\
\hline $\mathrm{C} / \mathrm{N}$ ratio ${ }^{* *}$ & $28.4 \pm 1.1^{\mathrm{a}}$ & $41.1 \pm 1.6^{\mathrm{b}}$ & $38.5 \pm 3.6^{\mathrm{b}}$ & $\mathrm{Chi}^{2}=$ \\
\hline Cuticular conductance & $7.5 \pm 0.68^{\mathrm{a}}$ & $5.5 \pm 0.91^{\mathrm{a}}$ & $7.5 \pm 1.05^{\mathrm{a}}$ & $\mathrm{F}=1$ \\
\hline
\end{tabular}

\section{Hosted file}

image1.emf available at https://authorea.com/users/352256/articles/476601-new-insightsinto-the-functional-ecology-of-paramo-plants-what-growth-forms-can-tell-us-about-plantfunctional-types

Figure A1. Visualization of the correlation matrix of 19 continuous functional traits. Positive correlations are shown in tone of blues and negative correlations in tones of red.

\section{Figure legends}

Figure 1. FAMD ordination of 42 plant species from páramo El Verjón-Matarredonda based on 20 functional traits. Axes labels display traits with the highest contribution on dimensions 1 and 2. Symbols show the three PFTs identified by the cluster analysis and colors show the seven growth forms in our dataset following the classification by Ramsay \& Oxley (Ramsay and Oxley, 1997). PFT-1 denoted with circles includes erect 
and prostrate herbs, one acaulescent rosette with soft leaves and tender leaves shrubs, PFT-2 denoted with triangles includes basal and stem rosettes, and PFT-3 denoted with squares includes prostrate and upright shrubs with tough leaves.

Figure 2. Clusters generated by HCPC of 42 plant species from páramo El Verjón-Matarredonda based on 20 functional traits. Labels display the most important traits that define each cluster. Symbols show the three PFTs identified and colors show growth forms using a simplified classification system where all erect and prostrate herbs are depicted as forbs, all basal, stem and acaulescent rosettes are depicted as rosettes and all prostrate and upright shrubs as shrubs. PFT-1 denoted with circles includes forbs and tender leaves shrubs, PFT-2 denoted with triangles includes all but one rosette, and PFT-3 denoted with squares includes only hard leaf shrubs.

Figure 3. Functional traits variation between the three PFTs identified in the paramo "El Verjón". The functional traits presented are: (A) plant height, (B) seed mass, (C) leaf area, (D) cuticular conductance, (E) specific leaf area, (F) leaf dry matter content, (G) leaf thickness, (H) leaf strength, (I) leaf C/N ratio, (J) leaf phosphorus content, $(\mathrm{K})$ leaf carbon content, (L) leaf nitrogen content, $(\mathrm{M})$ maximum light-saturated photosynthetic rate, $(\mathrm{N})$ leaf transpiration rate, $(\mathrm{O})$ water use efficiency, $(\mathrm{P})$ leaf water potential at pre-dawn, and (Q) leaf water potential at noon. P values from ANOVA and Kruskal-Wallis tests are presented; detailed statistics of the ANOVAS and Kruskal-Wallis test are in Table A1 in the appendix. Letters indicate statistical differences as determined by post-hoc Tukey's test and Wilcox test. The horizontal line inside the box plot indicates the median; the ends of the box are the upper and lower quartiles, and the lines outside of the box represent the highest and lowest values for each trait. 


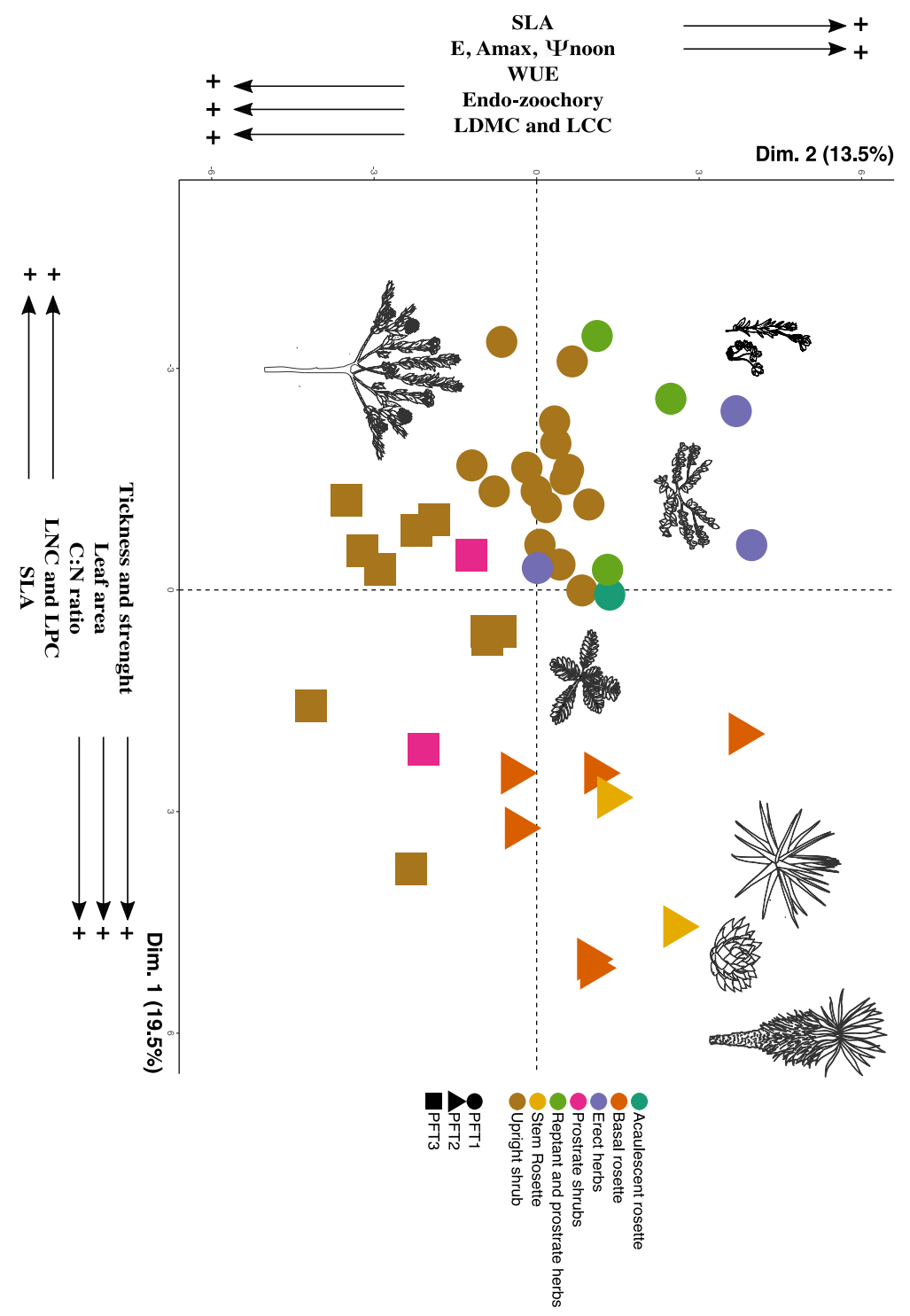




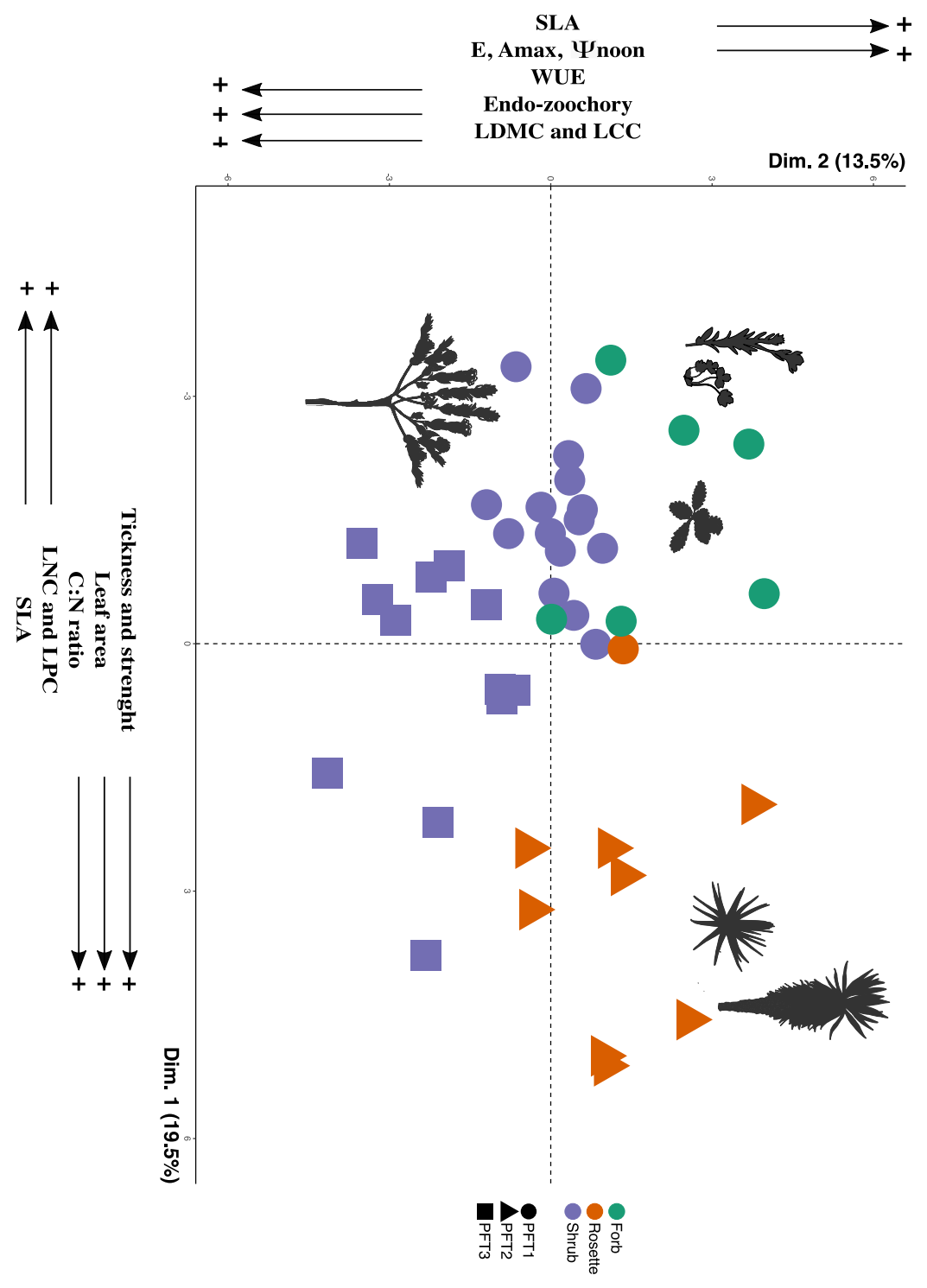




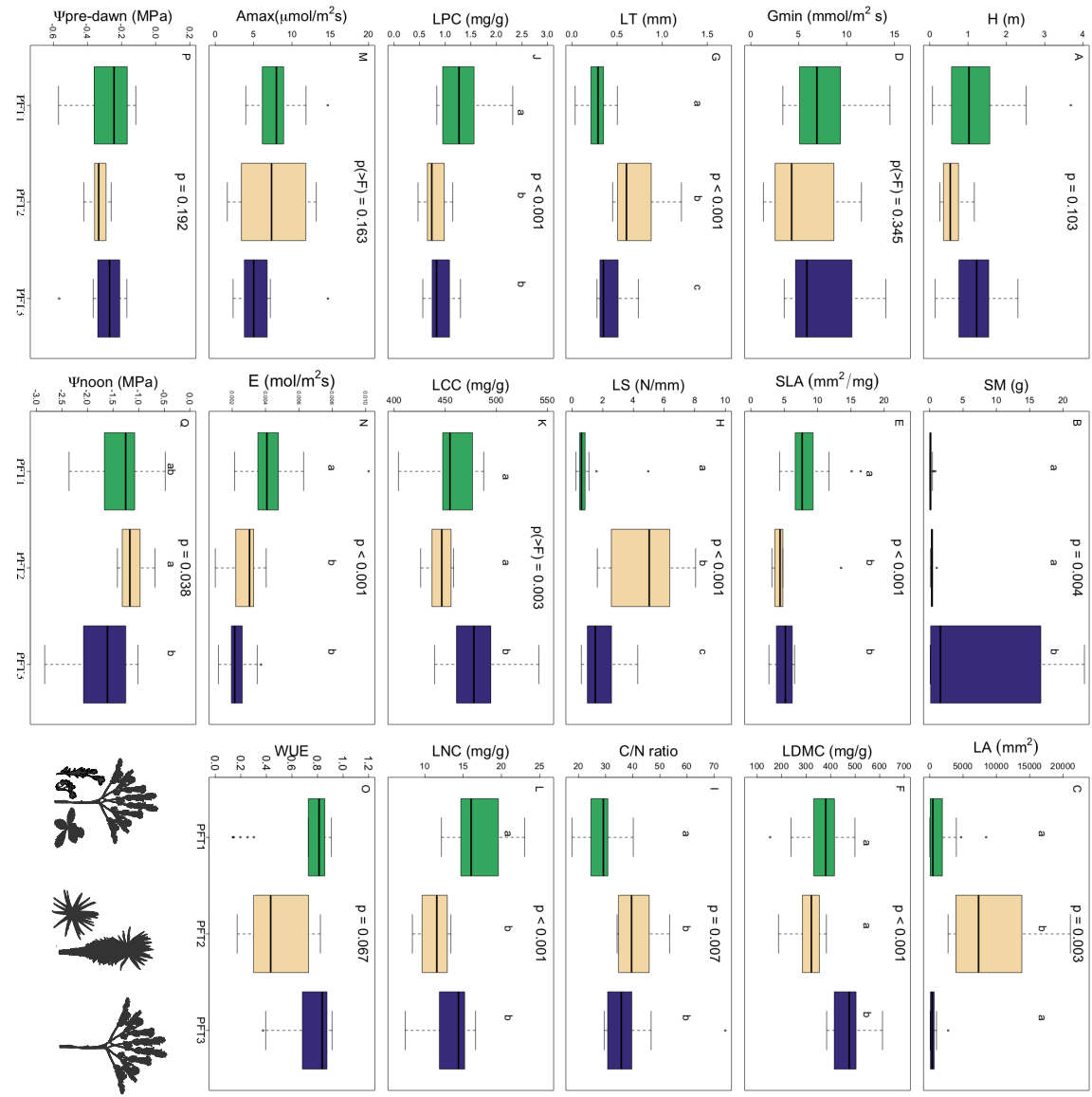

